\title{
INTRODUCTION: \\ THE YIJING AS A CHALLENGE FOR WESTERN METAPHYSICAL REFLECTION
}

\begin{abstract}
As an introduction to a special issue of the Journal of Chinese Philosophy on the Yijing and Western metaphysics, this article examines the variety of uses to which the Yijing has been put in the past and offers suggestions as to why the vast majority of Western philosophers, and even many recent Chinese philosophers, have tended to ignore it. Drawing on insights conveyed by the papers included in the special issue, as well as on various other recent research related to this topic, I argue that the Yijing has a largely untapped potential to be used by philosophers who seek to construct metaphysical arguments and systems. Everyone interested in gaining wisdom through philosophical reflection-whether their main focus is on Chinese thinkers, on Western thinkers, or on thinkers from other, more marginalized traditions-can benefit by accepting the challenge posed by this classical Chinese book of wisdom.
\end{abstract}

The great Chinese classic known as the Yijing《易經》-literally, the Book of Changes - is reputed to be the oldest book known to humankind. Despite the fact that it has served as the wellspring of wisdom for most of the great schools of thought in Chinese philosophy at least since Confucius, its relevance to serious metaphysical reflection has often gone unrecognized, even by philosophers working in the Chinese tradition over the past century. This, no doubt, is partly due to the well-known fact that the Yijing was originally used as, and is to this day often primarily regarded as, a tool for divination: if serious philosophical reflection in general has no proper role for fortune-telling, then surely metaphysics (the queen of the philosophical sciences, if not the model for all science whatsoever) is fully justified in shunning any book that smacks of such nonsense. This, at any rate, has been the typical line of thinking assumed by most respectable and respected philosophers, East and West, over the past few

STEPHEN R. PALMQUIST, Professor, Religion and Philosophy Department, Hong Kong Baptist University; Founder of the Hong Kong Philosophy Café (1999 to present); Guest Associate Editor, Journal of Chinese Philosophy. Specialties: Kant studies, philosophy of religion, theology of politics. E-mail: stevepq@hkbu.edu.hk 
centuries. Yet the Yijing is far more than just a handbook for fortunetelling. Its mathematically precise method of distinguishing between sixty-four hexagrams (or gua), each consisting of a set of six broken (yin) or solid (yang) lines arranged as a pair of trigrams, can be interpreted as a symbolic depiction of the essential building blocks of the ever-changing structure of human existence. This way of reading the Yijing poses a direct challenge to philosophers in every age and every tradition, for it suggests that the most profound way of reading the Yijing is as a handbook for metaphysics.

Fortunately, the past few decades have witnessed a surge of interest in the Yijing, on precisely the grounds that it is properly read as far more than just a fancy attempt at quasi-philosophical magic. The work of Chung-ying Cheng has been especially influential in this regard: he has tirelessly organized and/or helped promote a variety of recent Yijing conferences in China (e.g., in Anyang, October 2011, and annual conferences in Wuxi since 2015-to mention just a few examples) and has himself defended the relevance of the Yijing to Confucian ethics. ${ }^{1}$ Thus, in discussing the relationship between Kant's philosophy and Confucianism, he suggests at one point that it is primarily through their creative interpretations of the Yijing that Confucian philosophers "may be said to come to know the thing-in-itself in a sense that they come to realize it as an end of human life and that they could see it as an end of human action." " Numerous other scholars-too many to list in this brief introduction-have followed similar lines of thought, exploring the multi-faceted ways in which the Yijing and Western metaphysics have mutually challenging implications for each other.

Halla Kim's initial paper in this special issue observes that, even in the Chinese tradition, it is not always immediately apparent why a fortune-telling manual would have attracted so much attention from ancient Chinese scholars, whose main focus was normally on ethics-i.e., on forging a path of wisdom so that people would know how to live a good life. Kim points out that the ancient Chinese mindset dominated by Confucianism was so heavily influenced by the Yijing precisely because the ideas expressed in "the text of Zhouyi, with its mantic practices, contain a peculiar notion of normativity that can explain the idea of prescription found in the doctrine of the rectification of names." 3 This key Confucian doctrine combines ethics and metaphysics in a unique way, by directly linking right action to the proper designation of the real relationships that define human life. Because the Yijing systematically names sixty-four such basic relationships, and because the potential number of different types of change between these sixty-four possible starting-points is so extremely numerous (traditionally referred to with the proverbial expression, "the ten thousand things," but actually far greater than that ${ }^{4}$ ), the basic set of 
sixty-four gua can be taken as a blueprint for an orderly application of Confucius' doctrine and for the virtually infinite array of possible states of affairs that metaphysical reality exhibits. Moreover, this emphasis on a metaphysical way of reading the Yijing was not limited to Confucius himself; for as Tze-Ki Hon argues in the second contribution to this special issue, ${ }^{5}$ Wang Bi's approach to the Yijing offers a similarly rich resource for understanding its ontological implications.

Recent studies in the history of comparative philosophy have demonstrated that, during the first half of the eighteenth century, a surprising shift took place in reception of Chinese philosophy in Europe. As Martin Schönfeld has persuasively argued, ${ }^{6}$ European scholars were, in general, excited and open-minded about the ancient philosophical ideas coming out of China during the time of Gottfried Wilhelm Leibniz (1646-1716), but by the time Immanuel Kant (1724-1804) began his scholarly career, Chinese philosophy was being shunned and often being made into an object of ridicule. While this is not the place to discuss the reasons for such a dramatic cultural shift, it undeniably did happen, and the reasons were not all (or even primarily) philosophical in nature. As is well known, Leibniz not only knew about the Yijing, but wrote a journal article about it, in which he depicted the Yijing as being based on an expression of the very same mathematical logic that he himself had used as the basis for inventing calculus. ${ }^{7}$ The role of the Yijing not only in Leibniz' discovery of calculus, but also in his construction of a natural theology and in his overall metaphysical theory, is a theme well-deserving of further research.

Equally well known is that, by the time Kant began formulating the ideas that became the monumental and (in the post-Kantian West) almost universally influential Critical philosophy, Chinese philosophy had gone out of style. As a result, unlike Leibniz, Kant never mentions the Yijing and most of what he says about Chinese philosophy is negative-or cautiously neutral, at best. ${ }^{8}$ Nevertheless, my article ${ }^{9}$ in the special issue takes up the challenge of the Yijing in this potentially hostile context by presenting the latest installment of a series of essays that I have written in preparation for a forthcoming book, tentatively titled Changing the Changeless (see note 9, above). Theology, the most thoroughly metaphysical of the three "higher faculties" in Kant's understanding of the fourfold structure of the university (the other two higher faculties being law and medicine, while philosophy proper is the "lower faculty"), is a topic that many would regard as entirely absent from the Yijing, given the general earthly (i.e., practical, moral) focus of Chinese philosophy. But I argue that Kant's own theological reflections mirror the cautious approach toward theology adopted by Chinese philosophy in such a way that the Yijing can actually serve as a suitable interpretive 
framework for Kant's philosophical system in general, and for his theology in particular.

Ever since the middle of the twentieth century, the viability of metaphysics as a stand-alone discipline has been questioned in many Western philosophical circles, due to the fact that metaphysical reality is (as Kant had pointed out two centuries earlier) inaccessible without some form of interpretation. The discipline of hermeneutics has therefore come to take the pride of place that once belonged to ontology $-\mathrm{a}$ fact that has led Cheng to coin the term "onto-hermeneutics." The final article $^{10}$ in this special issue therefore explores the roots of Cheng's position in Gadamer's apparent abandonment of traditional metaphysics: Andrew Fuyarchuk argues that this "renewed" view of hermeneutics actually leaves ample room for the kind of "immanentist" perspective that is characteristic of both Confucian metaphysics and the Yijing, not to mention much of the Western metaphysical tradition that predates twentieth-century hermeneutic philosophy. Whether one agrees or disagrees with Fuyarchuk's specific and wide-ranging arguments regarding the proper interpretation of the Western metaphysical tradition, one thing is clear: his claim that the role of hermeneutics in Western philosophy must continue to be reassessed is virtually unassailable for anyone who wishes to take seriously the challenge that the new wave of Yijing research poses to all traditional forms of Western metaphysical reflection.

HONG KONG BAPTIST UNIVERSITY

Hong Kong, SAR, China

\section{ENDNOTES}

Acknowledgment of Copyrights and Credentials: My thanks to the contributors, and to the editors, Chung-ying Cheng and Linyu $\mathrm{Gu}$, for encouraging me to compile this collection of articles as a thematic issue of this journal. In addition, I would like to thank the Research Committee of Hong Kong Baptist University for providing funding for a grant which promoted this research.

1. See, for example, Chung-ying Cheng, "A Transformative Conception of Confucian Ethics: The Yijing, Utility, and Rights," in Confucian Philosophy: Innovations and Transformations, Supplement to Journal of Chinese Philosophy 38, no. 4 (2011), 7-28.

2. Chung-ying Cheng, "Theoretical Links between Kant and Confucianism: Preliminary Remarks," Journal of Chinese Philosophy 33, no.1 (2006), 11.

3. Halla Kim, "Confucianism before Confucius: The Yijing and the Rectification of Names," quoted from the second paragraph of the article published first in this special issue. Kim's article provides a helpful historical introduction to the origin of the Yijing and its relation to other ancient Chinese classics.

4. Each line can change into the equivalent line in any of the 64 gua (including itself). At the very least, with only one iteration of change, this means there are $6^{64}$ possible permutations. This works out to $6.334 \times 10^{49}$ possible distinct types of change, if 
just a single change in each line is treated independently from a single change in each of the other five. Of course, there are only four types of change: from yin to yin, from yin to yang, from yang to yin, or from yang to yang. But the meaning of a given yin or yang line will be different, depending on which of the 64 hexagrams it appears in.

5. Tze-Ki Hon, "The Ontology of Change: Wang Bi's Commentary on the Yijing," the second article in this issue.

6. See, e.g., Martin Schönfeld's paper titled "What Did Kant Learn from China, and Why Did He Not Own Up to It?" presented for a panel organized by the North American Kant Society and held at the American Philosophical Association's Pacific Division Meeting (April 2017).

7. See especially Leibniz' first book (1666), titled Dissertatio De Arte Combinatoria (On the Art of Combinations), and his later article, "Explanation of Binary Arithmetic, which Uses Only the Characters 0 and 1, with Some Remarks on Its Usefuless, and on the Light It Throws on the Ancient Chinese Figure of Fu Xi" (English translation available at: http://www.leibniz-translations.com/binary.htm). The original (French) version was published in Memoires de lÁcademie Royale des Sciences (1703), titled "Explication de l'arithmetique binaire, qui se sert des seuls caractères 0 et 1, avec des remarques sur son utilité, et sur ce qu'elle donne le sens des anciennes figures Chinoises de Fohy," and is reprinted as Chapter XXI in Leibnizens mathematische Schriften, vol. III, ed. C. I. Gerhardt, and vol. VII of Georg Heinrich Pertz (ed.), Leibnizens Gesammelte Werke (Halle: H. W. Schmidt, 1863 [second edition]), 223-227.

8. See, for example, the chapters collected in Part XII ("Kant on Asia and Asia in Kant") of Stephen R. Palmquist, ed., Cultivating Personhood: Kant and Asian Philosophy (Berlin: Walter de Gruyter, 2010): Alain-Marc Rieu, "The Kantian Model: Confucianism and the Modern Divide" (741-752); Klaus-Gerd Giesen, "Asian Hospitality in Kant's Cosmopolitan Law" (753-763); Rein Vos, "Doing Good or Right? Kant's Critique on Confucius" (764-776); Peter K. J. Park, "The Exclusion of Asia and Africa from the History of Philosophy: Is Kant Responsible?" (777-790); Soo Bae Kim, "Menschliche Autonomie als Aufgabe - der Autonomiebegriff in der Geschichtsphilosophie Kants" (791-798); and Simon Shengjian Xie, "Is Kant a Western Philosopher?" (799-807).

9. Stephen R. Palmquist, "Twelve Basic Theological Concepts in Kant and the Compound Yijing." The series began with a conference paper presented at the 2009 Kant in Asia conference, which was revised and republished as Stephen R. Palmquist, "The Unity of Architectonic Reasoning in Kant and I Ching," in Ibid., 811-821, then revised and reprinted again as "Architectonic Reasoning and Interpretation in Kant and the Yijing," Journal of Chinese Philosophy 38, no. 4 (2011), 569-583. Other previously published articles in the series are: Stephen R. Palmquist, "Mapping Kant's Architectonic onto the Yijing via the Geometry of Logic," Journal of Chinese Philosophy 39, Supplement (2012), 68-86; "Twelve Basic Philosophical Concepts in Kant and the Compound Yijing," Journal of Chinese Philosophy 42, nos.1-2 (2015), 143-162; and "Twelve Basic Concepts of Law in Kant and the Compound Yijing," Modernos e Contemporâneos I.1 (Jan./June 2017), 109-126.

10. Andrew Fuyarchuk, "Gadamer and the Yijing: Renewing Hermeneutics," the fourth article in this issue. 